\title{
VARIATIONS ON CHINA
}

Never to repair the wounds of heaven, but to lie in bed and dream of China burdened by small breasted women and friends who imply great sorrow in a touch as thousands of miles away love lies buried under the wall of China, memory vanishing like jars filled with tokens.

China's cities are wedded to the stars, her maps held together by rivers.

The women of China have small breasts.

The first born are kept in jars.

When the women of China sob the rivers unlock a secret door where Confucian perversions dominate.

The honey of heaven drips slowly from their breasts.

Where once I planned mass executions of my friends a telephone stands.

The line to China is busy.

Countless fingers grow from the phone as grievances increase.

I consider the manifest destiny of a leaf.

With Rimbaud-like motions my friends explore China.

What I remember barely fills a jar.

The moon hunts out its pirates.

My friends plunder telephone booths

in claustrophobic fits of passion.

I place the white thread of sorrow

around the neck of a small breasted woman.

The Chinese laugh at the moon.

They fill their ships with leaves and dreams.

Endless sorrows plague their government.

They plan mass executions of my friends.

Their gold outlives their beards.

Honey drips. 
My small breasted friends are strangled by sorrow. My pain resides beneath the shadow of the moon where the wounds of heaven pour forth oriental madness to kill our dreams.

And my Chinese friends, numerous as telephones, babble on like rivers ... like rivers.

Barry Seiler

\section{ICEHOUSE}

The wagons have rumbled away

from this wooden horizon bearing the last blue blocks.

In Winter, we'd bolt over the fresh sawed channels, cut that the beast might breathe,

in Summer trail the drips for chips of bone to wedge our mouths open against the waving heat. If you climbed way up the conveyor to the small door open at the top you had two alternatives, both blue. 